\title{
Inhimilliset toimintamahdollisuudet oikeudenmukaisuuden ja tasa-arvon kriteereinä
}

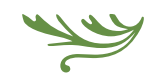

NÄKÖKULMIA TUTKIMUKSEEN -puheenvuorossaan Kristiina Brunila (Aikuiskasvatus 1/2014) esittelee Helsingin yliopiston käyttäytymistieteellisen tiedekunnan uuden kasvatuksen ja koulutuksen sosiaalisen oikeudenmukaisuuden ja tasa-arvon professuurin.

Kuvatessaan suunnitelmiaan profesuuriin liittyen hän peräänkuuluttaa teorioita ja tutkimusta, joiden "tulisi auttaa ymmärtämään ongelmia, joita yhteiskunnassamme ja mahdollisesti myös omassa ajattelussamme on, mutta myös tarjoamaan ymmärrystä ajatella ja toimia toisin".

Tartumme kommentaarissamme Brunilan visioimaan toisinajatteluun, "pieneen idealismiin" ja "uuden kehittelyyn". Otamme kantaa ajankohtaiseen keskusteluun tarjoamalla uuden ja täydentävän perspektiivin: Inhimillisten toimintamahdollisuuksien lähestymistavan ${ }^{1}$ (capabilities approach). Näemme siinä potentiaalia suomalaiseen koulutuspoliittiseen suunnitteluun, toteutukseen ja arviointiin.

\section{MITEN PERUSKOULUN ALAMÄKEEN REAGOIDAAN?}

Viimeaikaisessa kasvatus- ja koulutuskeskustelussa on kiinnitetty huomiota sekä peruskoulun että peruskoulun jälkeisen koulutuksen, mukaan lukien korkeakoulutuksen, haasteisiin ja ongelmiin.

Peter Johnson ja Pasi Sahlberg kritisoivat Helsingin Sanomien Vieraskynässä 20. elokuuta 2014 pinnallisten ja lyhytnäköisten osauudistusten (esim. oppivelvollisuusiän nostaminen) tehottomuutta oppimismotivaation rapistumisen, eriarvoisuuden lisääntymisen, opettajien uupumisen ja peruskoulun jälkeisen koulutuksen varhaisen keskeyttämisen hoitamisessa.
Elokuisessa Korkeakoulututkimuksen XII kansallisessa symposiumissa Jyväskylässä Opetus- ja kulttuuriministeriön ylijohtaja Tapio Kosunen kiinnitti huomiota kasvavaan alueelliseen, sukupuolten väliseen ja sosioekonomiseen eriarvoistumiseen. Helsingin Sanomien pääkirjoitussivulla nostettiin 12. syyskuuta 2014 esiin tasa-arvo-ongelma, joka perustuu poikkeuksellisen suuriin eroihin tyttöjen ja poikien lukutaidossa.

Opetusministeri Krista Kiuru on viimeisimpien PISA-tulosten valmistuttua tuonut esiin huolensa lasten ja nuorten osaamistason merkittävästä laskusta. Kasvatuspsykologian professori Kirsti Lonka taas on kiinnittänyt huomion heikkoon kouluviihtyvyyteen ja heikkoon motivaatioon mahdollisesti jopa merkittävämpinä asioina kuin varsinaiset PISA-tulokset.

Useimmissa puheenvuoroissa 'mahdollisuuksien tasa-arvo' on nähty suomalaisen koulutuksen menestystarinan perustana, jonka kuitenkin nähdään olevan tienhaarassa.

Opetusministeri Kiurun mukaan (mm. Huomenta Suomen lähetys 13. elokuuta 2014) koulutuspoliittisessa suunnittelussa ja toteutuksessa tarvitaan uudistuksia, jotka vastaavat tämän ajan odotuksiin, ja jotka hänen mukaansa ovat ennen kaikkea pedagogisia. Kiuru ehdottaa koulujen ja opettajien työvälineiden päivittämistä nykypäivän tarpeita vastaaviksi ja koulujen digitalisointia, kuten tablettien hankkimista (ks. myös Horizon Europe: "Koulut 2014" -raportti).

Johnson ja Salhberg puolestaan vaativat keskittymistä opetuksen pullonkauloihin ja kokonaisvaltaiseen kehitystyöhön ja peräänkuuluttavat oppilaiden oppimismotivaation, uteliaisuuden, oppimisen ilon ja intohimon vahvistamista. 
Edellä mainittuihin haasteisiin, uudistuksiin ja kehitystyöhön liittyen ja pureutuen kasvatuksen ja koulutuksen sosiaalisen oikeudenmukaisuuden ja tasa-arvon professuuri on, kuten Brunila toteaa, merkittävä sekä kansallisesti että kansainvälisesti.

Myös Johnson ja Sahlberg huomauttavat, että eri puolilla maailmaa seurataan mielenkiinnolla, miten peruskoulun alamäkeen Suomessa reagoidaan.

\section{KEHYS KOULUTUKSEN LAAJEMPAAN TARKASTELUUN}

Oppimistulosten laskeva trendi on huolestuttava ennen kaikkea yhdistettynä samanaikaisesti kasvavaan heikkoon koulussa viihtymiseen ja oppimismotivaatioon, joiden oletetaan liittyvän toisiinsa.

Inhimillisten toimintamahdollisuuksien lähestymistapa ja käsitteistö voivat tarjota kehyksen ja työkaluja oppimisen, motivaation ja kouluviihtyvyyden yhteyksien tarkasteluun laajempana kokonaisuutena, osana koulutuksen eriarvoistumista, tasa-arvopolitiikan ja tasa-arvotyön toteutusta. Lähestymistapaa ei Suomessa toistaiseksi ole juuri sovellettu koulutuksen tutkimuksessa.

Viittaamme Sirkku Hellsteniin, joka lähes 20 vuotta sitten totesi Niin \& Näin -lehden kirjoituksessaan lähestymistavan sopivan hyvin lähtökohdaksi, kun pohditaan sekä moraalisia että rationaalisia perusteluja hyvinvointivaltion sosiaalipolitiikalle, myös koulutuspolitiikalle, ja hyvän elämän ja oikeudenmukaisen yhteiskunnan perusteita puhtaasti poliittisten ja taloudellisten näkökulmien rinnalla (ei vaihtoehtoina).

Nobel-palkitun taloustieteilijän Amartya Senin (esim. 1985, 1993, 1999) ja filosofi Martha C. Nussbaumin (esim. Nussbaum 2000; Nussbaum \& Sen 1993; Comin \& Nussbaum 2014) kehittämän lähestymistavan alkuperäinen kehityspainotteinen orientaatio on muutaman vuosikymmenen aikana levittäytynyt kehittyvien maiden tutkimuksesta niin sanottuun globaaliin pohjoiseen.

Taloustieteellinen ja eettis-filosofinen painopiste on samalla laajentunut hyvinvoinnin, sosiaalisen oi- keudenmukaisuuden ja yhteiskunnallisen muutoksen tarkasteluun lähestulkoon kaikilla yhteiskunta- ja ihmistieteiden aloilla, myös kasvatuksessa ja koulutuksessa (Robeyns 2006; Unterhalter 2003; Walker 2010; Walker \& Unterhalter 2007).

Esimerkiksi saksalaisen Bielefeldin yliopiston Center for Education and Capabilities Research on koordinoinut useita ja mittavia EU-rahoitteisia toimintamahdollisuus-lähestymistapaan nojautuvia ja sen käsitteitä soveltavia sosiaali- ja koulutuspoliittisia kehittämishankkeita.

\section{KÄSITTEELLISIÄ EPÄTÄSMÄLLISYYKSIÄ}

Toisaalta juuri käsitteistön moniselitteisyyden ja epätarkkuuden vuoksi lähestymistapaa on myös kritisoitu: pelkästään peruskäsitteiden 'toimintamahdollisuudet' (capabilities) ja 'toiminnot/saavutukset' (functionings) määrittelyä pidetään ongelmallisena.

Lisäksi lähestymistavan sisällä on perustavaa laatua olevia eroavaisuuksia ja erimielisyyksiä siitä, miten inhimilliset toimintamahdollisuudet identifioidaan ja määritellään.

Esimerkiksi Sen on systemaattisesti kieltäytynyt identifioimasta ja määrittelemästä keskeisiä toimintamahdollisuuksia toisin kuin Nussbaum, joka on laatinut listan niistä kymmenestä toimintamahdollisuudesta, jotka jokaisen yhteiskunnan tulee jäsenilleen tarjota.

Käsitteellisten epätäsmällisyyksien pohdinnan ja teoreettisten debattien sijaan puheenvuoromme tarkoitus on esittää yksi tapa ymmärtää käsitteitä ja erityisesti niiden tarjoamaa näkökulmaa tarkastella koulutusta ja hyvinvointia.

Senin lähtökohtana toimintamahdollisuuksien lähestymistavan kehittämisessä voidaan pitää hänen esittämäänsä kritiikkiä sitä tietopohjaa kohtaan, miten inhimillinen kehitys ja hyvinvointi määritellään. Näin ollen myös: miten kehitystä ja hyvinvointia tavoitellaan $j a$ arvioidaan.

Ongelma on siten sekä ontologinen että metodologinen, ja siksi useat poliittiset aloitteet ja toimenpi- 
teet koetaan riittämättömiksi ja väärin suunnatuiksi.

Koulutuksen ja kehityksen asiantuntijat ovat samoilla linjoilla. Toimintamahdollisuuslähestymistavan mukaisesti ymmärrettynä koulutuksen ja opetuksen kehitystyössä on huomioitava,

- mitä ihmiset arvostavat ja arvottavat koulutuksessa,

• mitä he pitävät tärkeänä ja merkityksellisenä elämässä ja

- miten koulutus ja kouluttautuminen sijoittuvat niihin moninaisiin olemisten ja tekemisten (beings and doings) muotoihin, joita ihmisillä on syytä (syystä tai toisesta) pitää merkityksellisinä ja arvokkaina.

Lähestymistavan yksiselitteisen normatiivinen prinsiippi on, että kaikkien yhteiskuntapoliittisten toimenpiteiden pitäisi olla suunnattu edistämään inhimillistä hyvinvointia (well-being) ja toimijuutta (agency), joiden kummankin kaksi perusulottuvuutta ovat saavutukset (achievements) ja vapaudet (freedoms).

\section{KATSE MAHDOLLISUUSHORISONTTIIN}

Yhdistämällä edelliset neljä peruselementtiä ja -käsitettä saadaan muodostettua kehys, jonka puitteissa esimerkiksi opetuksen ja koulutuksen kentällä operoidaan.

Koulutukselliset toiminnot (well-being achievements $=$ functionings $)$ ovat olemisen ja tekemisen muotoja, joita oppijat ovat saavuttaneet ja joita kansalliset ja kansainväliset arviointimekanismit pääosin seuraavat. Tällaisia ovat esimerkiksi matematiikan arvosana ja tutkintojen märä. Koulutukselliset toimintamahdollisuudet (well-being freedoms = capabilities) puolestaan koostuvat sekä resursseista että mahdollisuuksista ja vaihtoehdoista tavoitella ja saavuttaa niitä koulutuksellisia toimintoja, joita oppijat pitävät arvokkaina.

Koulutuspolitiikan suunnittelussa ja toteutuksessa toimintamahdollisuuksien soveltaminen merkitsisi esimerkiksi opetusministeri Kiurun ehdottamaa digitalisointia, mutta vielä tärkeämpää olisi kehittää sitä, mitä välineillä tehdään ja miten resursseja hyö- dynnetään oppimisen ja muiden koulutuksellisten tavoitteiden saavuttamiseksi.

Toimintamahdollisuuslähestymistavan terminologian mukaisesti koulutuksen kehittämisen painopisteen pitäisi siis olla niissä tekijöissä, jotka mahdollistavat koulutuksellisten toimintojen saavuttamisen: aiemmin esitettyjä esimerkkejä käyttäen muun muassa motivoinnissa sekä uteliaisuuden, oppimisen ilon ja intohimon vahvistamisessa käyttää digitaalisia resursseja.

Inhimillisten toimintamahdollisuuksien lähestymistavan positiosta katsottuna mahdollisuushorisontin huomioimatta jättämisestä seuraa riittämätön ja vääristynyt ymmärrys koulutuksellisesta hyvinvoinnista.

\section{KESKUSTELUA OPPIJOITA KUUNNELLEN}

Oppijoiden välillä on kuitenkin eroavaisuuksia siinä, miten he hyödyntävät toimintamahdollisuuksia sekä tekevät koulutuksellisia valintoja ja päätöksiä. Tämä voi johtua alussa esitetyistä alueellisista, sukupuolten välisistä ja sosio-ekonomisista eroista.

Otamme tarkasteluun hieman toisenlaisen 'toimijuusnäkökulman'. Voi esimerkiksi olla täysin peruskouluikäisen lapsen ja peruskoulun päättäneen nuoren oman toimijuuden ja intressien mukaista (agency achievements) käyttää padia peli- ja koodaamistaitojen kehittämisessä. Toisaalta on lapsen toimijuusvapauksien (agency freedoms) rajoittamista, jos padin käyttö rajoitetaan pelkästään kouluun ja matemaattisten taitojen oppimiseen.

Oppilas tai nuori voi myös preferoida kouluun menemisen sijaan kotiin jäämistä, jolloin hän voisi oman näkemykensä mukaan paremmin kehittää digitaalisia taitojaan omien välineidensä avulla. Tämän tyyppisestä lapsiin ja nuoriin kohdentuvasta vapausdilemmasta ollaan lähestymistavan sisällä yhtä mieltä siitä, että toimijuusvapauksia voidaan rajoittaa toimijuussaavutusten kustannuksella koulutuksellisten toimintojen saavuttamiseksi. Näin pyritään turvaamaan se, että lapset ja nuoret ovat kehittäneet riittävät omat toimintamahdollisuudet. 
Koulutuspoliittisen suunnittelun ja toteutuksen kannalta haasteellisinta on saattaa koulutukselliset olemisen ja tekemisen muodot keskusteluyhteyteen yksilöllisten toimijuussaavutusten kanssa. Tässä tehtävässä nousevat kriittiseen asemaan koulutukselliset toimintamahdollisuudet.

Inhimillisten toimintamahdollisuuksien lähestymistavan perusperiaate on, että opetuksen ja koulutuksen kokonaisvaltainen, eriarvoistumisen vähentämiseen pyrkivä kehittämistyö perustuu ymmärrykselle siitä, minkälaisen arvon ja relevanssin ihmiset koulutukselle ja kouluttautumiselle antavat. Tämä edellyttää äänen antamista "asianomistajille", toisin sanoen oppijoille, mikä onkin tärkeä inhimillisten toimintamahdollisuuksien lähestymistavan perusperiaate.

Brunilan tavoin toivomme keskustelua, oppijoita kuunnellen, ja sitä kautta saavutettua jaettua ymmärrystä ajatella ja toimia toisin.

\section{Mari-Anne Okkolin}

FT, YTM tutkijatohtori koulutuksen, kehityksen, tasa-arvokysymysten ja sosiaalisen

oikeudenmukaisuuden parissa

University of Free State, Etelä-Afrikka

Jyväskylän yliopisto

\section{Elina Lehtomäki}

KT, dosentti, yliopistotutkija

Jyväskylän yliopisto

Helsingin yliopisto

Rauni Räsänen

professori (emerita), kasvatustiede,

kansainvälisyyskasvatus

Oulun yliopisto

\section{LÄHTEET}

Comin, F. \& Nussbaum, M. C. (toim.) (2014). Capabilities, Gender, Equality. Towards Fundamental Entitlements. Cambridge: Cambridge University Press.

Hellsten, S. (1995). Toimintamahdollisuudet sosiaalipolitiikan oikeudenmukaisuuden kriteereinä. Niin \& Näin, 2/95.

Nussbaum, M. (2000). Women and Human Development: The Capabilities Approach. Cambridge: Cambridge University Press.

Nussbaum. M. \& Sen. A. (toim.) (1993). The Quality of Life. WIDER Studies in Development Economics. Oxford: Oxford University Press.

Robeyns, I. (2006). Three Models of Education: Rights, Capabilities and Human Capital. Theory and Research in Education, 6:1, 68-84.

Sen, A. (1985). Well-being, Agency and Freedom: The Dewey Lectures 1984. Journal of Philosophy 82:4, 169-221.

Sen, A. (1993). Capability and Well-being. Teoksessa Nussbaum M. \& Sen A. The Quality of Life. WIDER Studies in Development Economics. Oxford: Oxford University Press, 30-53.

Sen, A. (1999). Development as Freedom. Oxford: Oxford University Press.

Unterhalter, E. (2003). Crossing Disciplinary Boundaries: the Potential of Sen's Capability Approach for Sociologists of Education. British Journal of Sociology of Education 24:5, 665-669.

Walker, M. (2010). Capabilities and Social Justice in Education. Teoksessa Otto, H-U. \& Ziegler, H. Education, Welfare and the Capabilities Approach. Opladen: Barbara Budrich Publishers, 155-179.

Walker, M. \& Unterhalter, E. (toim.) (2007). The Capability Approach. Teoksessa Amartya Sen's Capability Approach and Social Justice in Education, 1-18. New York: Palgrave Macmillan.

\section{VIITTEET}

1 Lähestymistavasta on suomenkielellä käytetty enemmän termiä 'toimintavalmiudet', mutta mielestämme 'valmiudet' ja 'kyvykkyys' -diskurssi on liian kapea eikä se tavoita lähestymistavan perusideaa, jota 'toimintamahdollisuudet' kuvaa paremmin. 